\title{
Development Level of Brand Management at Banks in Bosnia and Herzegovina
}

\author{
Beriz Čivić $^{1}$ \\ ${ }^{1}$ Faculty of Economics, University of Tuzla, Tuzla, Bosnia and Herzegovina \\ Correspondence: Beriz Čivić, Faculty of Economics, University of Tuzla, Univerzitetska 8 Street, 75000 Tuzla, \\ Bosnia and Herzegovina.
}

Received: October 23, 2017

Accepted: November 20, 2017

Online Published: December 1, 2017

doi:10.5539/ibr.v11n1p66

URL: https://doi.org/10.5539/ibr.v11n1p66

\begin{abstract}
The paper analyzes the development level of the brand management at the banks operating on the market of Bosnia and Herzegovina $(\mathrm{BiH})$. The aim of the research was to establish to what extent certain elements of brand management are present and whether the brand management decisions are made based on the systematic or the ad hoc approach. The research results indicate that five banks in $\mathrm{BiH}$ have a very high level of brand management development. Making brand management related decisions for these banks is based on the systematic approach. It has been established that other banks in $\mathrm{BiH}$ have a lower level of brand management development and that for most banks in this group the process of making brand management decisions is characterized by the ad hoc approach.
\end{abstract}

Keywords: brand management, banks, making brand development decisions

JEL classification: M31

\section{Introduction}

Market success of business subjects depends on many internal and external factors. Besides other internal factors, the one particularly important is brand management. The activities within brand management focus on an integral approach to the long term development of the preferred position in customers' minds towards a specific company, its products and services. The integral approach in this case includes constant, clear and full scale communication with customers (clients) on the one side, and the high quality offer of products and services adapted to customers' needs and opportunities on the other.

The assumption of a successful long term relation with customers (or the customer loyalty assumption) lies in achieving their constant satisfaction and trust. This issue is of particular importance on the market of banking services. The reason lies in the fact that banking services include direct financial transactions, which requires a high level of mutual trust between the bank and the client. This is why brand management is of extreme importance for banks as the brand is the main element for achieving recognition by clients and differentiation in relation to competitors.

This is why successful banks pay much attention to brand management as the success of brand management process directly determines bank's positioning in customers' minds and consequently determines bank's market success. Bank's market success is, among other things, determined by clients' satisfaction and trust and is manifested primarily by the amount of granted credits and collected deposits.

In order to achieve a clear and recognizable positioning by their clients, banks use corporate brand (bank's brand) as the focal point that serves to pinpoint the values that need to be communicated with clients. In other words, corporate brand is used to achieve connection between the clients and the bank, based on the values considered to be able to motivate the clients to develop their relations with the bank. Unlike the companies offering physical products, banks see the role and importance of corporate brand as much more expressed. Creating brand portfolios is significantly less used by banks than the companies in the manufacturing sector.

\section{Literature Review}

Among other things, in brand management it is important to differentiate to dimensions of a brand. The first dimension includes the visible elements of a brand (name, sign, color combination, etc.) and their importance is 
related to achieving visual recognition by customers or visual differentiation from the competitors. This group of elements makes the visual identity of a brand. The other dimension of a brand includes the invisible elements of a brand which are the values associated to the given brand (for example tradition, quality, innovativeness, reliability, trust, etc.). The importance of this dimension of a brand is related to the efforts to use the presented (promoted) values in order to develop the psychological relationship with the clients thus taking the desired position in customers' minds, which is important for achieving clients' affinity to brand owner (its services) when deciding on purchase. This group of elements makes the image of a brand.

Keller specifies a series of elements which make brand important to the company and customers/clients (Keller, 2003): a) brand for the company means: the means of identification for easier using and tracking a product, the means of legal protection of unique characteristics of offer, indicator of the quality level for customers, means of adding unique associations to a product, the source of competitive advantage, source of financial income; $b$ ) brand for customers means: identification of product's origin, ability to define manufacturer's responsibility, risk reduction, reduced costs of searching for a product, promise, quality assurance by manufacturer, symbolic means, quality sign.

Brand is created when marketing efforts add value to the product when comparing it to other products with similar characteristics. By creating a brand, company makes its offer different from that of the competitors. All brands, including the good ones as well as the bad ones, created from customers' experience (Šapić, 2007). The importance of brand is supported by the results obtained by the German consulting company BBDO Consulting. In order to show the influence of brands on stock price, they compared the effect on the financial market of 23 out of 30 companies listed on the Frankfurt stock exchange. A huge difference in stock prices that emerged emphasized the general importance of brands. The companies with strong brands had a much faster recovery than those with the weaker brands after the stock market "collapsed" following the 9/11 attack in New York in 2001. Strong brands provide companies with higher return on invested capital (Kotler \& Ferč, 2007).

Brand is one of the possible ways to reduce the risks for customers to an acceptable level. What is especially important is personal experience with the brand, experience of other people and the general perception of the brand by the referential group. Brand certainly means easier decision making while purchasing (Vranešević, 2007). Brand management is a set of activities related to launching the brand on the market and managing the brand during its life cycle. It is a strategic issue, with the aim of creating and increasing the value of the brand for both, customers and the company (Veljković, 2010). The activities of the managers working on the development of bank's brand focus on: a) identifying the features of the services important to clients, and b) connecting the features with the brand in order to motivate the clients to accord their trust to them by choosing their bank for using financial services. It is important for the bank to carry out its operations within brand management in the way different from its competitors so as to create the messages that would enable their clients to make clear and relevant arguments when making the decision on which bank to choose. The final decision on the fate of every brand, including those of banks, is made by the clients, through their decision on using banking services. A clear signal that brand managers are on track towards creating a successful brand is achieving client loyalty.

As Leslie de Chernatony claims, the task of ensuring an integrated branding strategy is one that necessitates working with many people across numerous functional specialism's and throughout many levels of seniority. By adopting a planned approach, everyone is more likely to understand the brand objectives and the role they need to play in supporting the brand. The process of building and sustaining brands includes: brand vision, organizational culture, brand objectives, audit brand sphere, brand essence, internal implementation, brand resourcing and brand evaluation (de Chernatony, 2006).

Brand management covers a series of mutually connected stages that need to be planned with quality and implemented efficiently. Brand management must not be an ad hoc activity as it is a strategic issue for every company. There are more approaches to the systematization of stages integral to brand management process. The literature most often cites the process of creating and improving brand values given by Scott M. Davis in his works: Brand Asset Management-Driving Profitable Growth Through Your Brands and Brand Asset Management: How businesses can profit from the power of brand. Davis claims that the process of creating and developing a brand should consist of 11 steps grouped into four stages (Davis, 2002):

- Stage 1 - Developing a Brand Vision

Step 1; Define the strategic and financial goals and objectives that your brand should help achieve

- $\quad$ Stage 2 - Determining Your Brand Picture 
Step 2; Determining your brand's image

Step 3; Creating your brand's contract

Step 4; Crafting a brand-based customer model

- $\quad$ Stage 3 - Developing a Brand Asset Management Strategy

Step 5; Positioning your brand for success

Step 6; Extending your brand

Step 7; Communicating your brand's position

Step 8; Leveraging your brand to maximize channel influence

Step 9; Pricing your brand at a premium

- Stage 4 - Supporting a Brand Asset Management Culture

Step 10; Measuring your return on brand investment

Step 11; Establishing a brand-based culture.

This process of creating and de veloping brand is widely accepted in the scientific circles and that is why this approach is used in the empirical research into the development of brand management for the banks in $\mathrm{BiH}$.

\section{Research Methodology}

The aims of the research are to establish:

a) The presence of certain elements of brand management at the banks in $\mathrm{BiH}$;

b) Whether the decisions related to brand development are made based on the systematic or ad hoc approach.

Research hypotheses:

Hypothesis 1. There is no high level of development of brand management process for most banks in $\mathrm{BiH}$;

Hypothesis 2. For most banks in BiH the decisions related to brand management are made based on the ad hoc approach.

Data collection: The data presented in the following part of the paper are the result of the primary research. The data were collected from the banks in $\mathrm{BiH}$. According to the data of the Central Bank of $\mathrm{BiH}$ (http://cbbh.ba/Content/Read/7), there are twenty banks currently operating on the market of $\mathrm{BiH}^{1}$. Some banks, due to the specific legal environment, have two legally separated business entities on the market of $\mathrm{BiH}$ but their business policies on the market of $\mathrm{BiH}$ are integrated and that is why such banks are treated as one entity or one subject. All the banks were invited to participate in the research. Eighteen banks filled in the questionnaire and two banks did not want that. The data were collected by means of a survey (technique of written structural survey, the form of data collection is the web questionnaire). The questionnaire was filled in by general managers (president of the management board) in the banks. The data were collected in February 2017.

\section{Result Anal ysis and Discussion}

The paper observed four variables related to brand management: a) presence of formal procedures for making decisions related to brand management (used to establish whether the banks use the systemic or the ad hoc approach to making decisions on the brand), b) stages in the process of creating and improving certain elements of the brand, c) sources of data for making decisions related to the development of the brand, and d) characteristics of the approach to brand management.

\subsection{Presence of the Systemic Approach to Brand Management for the Banks in BiH}

What is extremely important for market success is to base the creation and development of brand on the systemic approach. This includes the existence of a clear and full scale plan of actions in the case when certain elements of the brand are changed or when new brand related elements are created. The research results indicate that 8 banks $(44 \%)$ have the document with the formal procedures that a) regulate the order of the steps and the content

${ }^{1}$ That are: 1. Addiko Bank, 2. ASA Banka, 3. Bor Banka, 4. Bosna Bank International, 5. Intesa Sanpaolo Banka, 6. Komercijalna banka (Commercial Bank), 7. Komercijalno-investiciona banka (Commercial Investment Bank), 8. MF banka, 9. NLB Banka, 10. Nova banka, 11. Pavlović International Bank, 12. ProCredit Bank, 13. Raiffeisen Bank, 14. Razvojna banka F BiH (Development Bank of BiH Federation), 15. Sberbank BH, 16. Sparkasse Bank, 17. UniCredit Bank, 18. Union banka, 19. Vakufska banka, and 20. ZiraatBank BH. 
of the activities undertaken when decisions are made related to bank's brand, and b) specify the organizational units in charge of performing the given activities within the brand management process (Figure 1).

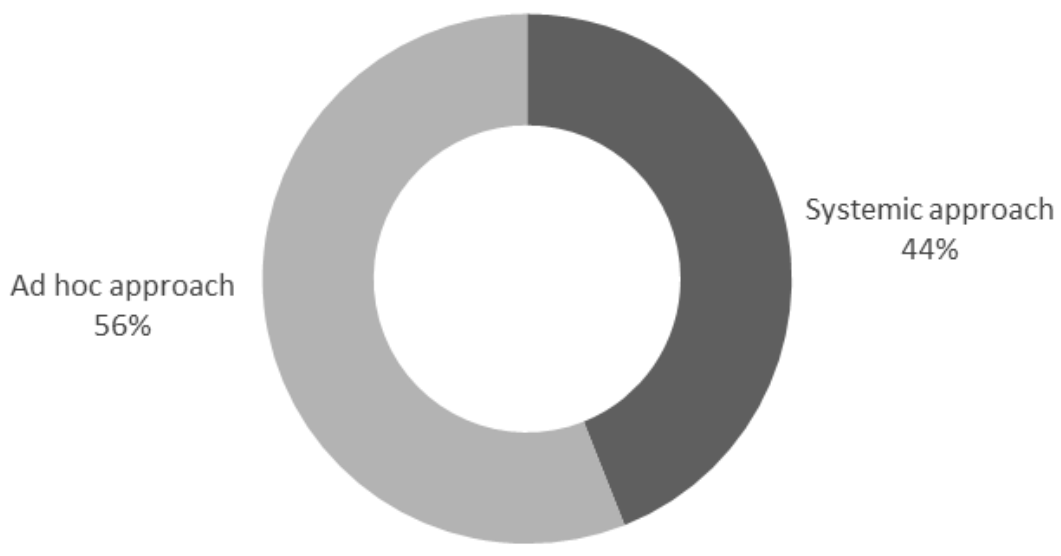

Figure 1. Systemic vs. ad hoc approach in brand management for the banks in BiH (Author's research)

Ten banks (56\%) do not have the regulations for making decision related to brand management. The brand management process at these banks is characterized by the ad hoc approach according to which the solutions related to brand management are defined on a case-by-case basis.

\subsection{The Content of the Brand Management Process for the Banks in BiH}

The research was aimed at establishing the extent to which brand management for the banks operating on the market of $\mathrm{BiH}$ is implemented by the process defined by Davis (2002), which includes four stages and 11 steps (as explained in the previous section). The research results are given in Table 1. Most of the banks (78\%) practice the promotional activities related to communicating the brand's position (step 7). The next most registered group of activities (present for $67 \%$ of the subjects) is related to determining the brand's image (step 2), followed by the activities Davis grouped as steps 1 and 5, registered for $61 \%$ of the subjects.

Table 1. Presence of individual steps in the brand management process for the banks in $\mathrm{BiH}$

\begin{tabular}{|c|c|c|c|c|}
\hline Stages & Steps & No & Yes & $\sum$ \\
\hline $\begin{array}{l}\text { Stage } 1 \\
\text { Developing a } \quad \text { Brand } \\
\text { Vision }\end{array}$ & $\begin{array}{l}\text { Step 1; } \\
\text { Define the strategic and financial goals and objectives that } \\
\text { your brand should help achieve }\end{array}$ & $\begin{array}{c}7 \\
(39 \%)\end{array}$ & $\begin{array}{c}11 \\
(61 \%)\end{array}$ & $\begin{array}{c}18 \\
(100 \%)\end{array}$ \\
\hline Stage 2 & Step 2; & 6 & 12 & 18 \\
\hline Determining Your Brand & Determining your brand's image & $(33 \%)$ & $(67 \%)$ & $(100 \%)$ \\
\hline Picture & $\begin{array}{l}\text { Step 3; } \\
\text { Creating your brand's contract }\end{array}$ & $\begin{array}{c}10 \\
(56 \%)\end{array}$ & $\begin{array}{c}8 \\
(44 \%)\end{array}$ & $\begin{array}{c}18 \\
(100 \%)\end{array}$ \\
\hline & $\begin{array}{l}\text { Step } 4 \text {; } \\
\text { Crafting a brand-based customer model }\end{array}$ & $\begin{array}{c}10 \\
(56 \%)\end{array}$ & $\begin{array}{c}8 \\
(44 \%)\end{array}$ & 18 \\
\hline Stage 3 & Step 5; & 7 & 11 & 18 \\
\hline Developing a Brand Asset & Positioning your brand for success & $(39 \%)$ & $(61 \%)$ & $(100 \%)$ \\
\hline \multirow[t]{7}{*}{ Management Strategy } & Step 6; & 10 & 8 & 18 \\
\hline & Extending your brand & $(56 \%)$ & $(44 \%)$ & $(100 \%)$ \\
\hline & $\begin{array}{l}\text { Step 7; } \\
\text { Communicating your brand's position }\end{array}$ & $\begin{array}{c}4 \\
(22 \%)\end{array}$ & $\begin{array}{c}14 \\
(78 \%)\end{array}$ & $\begin{array}{c}18 \\
(100 \%)\end{array}$ \\
\hline & Step 8; & 11 & 7 & 18 \\
\hline & Leveraging your brand to maximize channel influence & $(61 \%)$ & $(39 \%)$ & $(100 \%)$ \\
\hline & Step 9; & 12 & 6 & 18 \\
\hline & Pricing your brand at a premium & $(67 \%)$ & $(33 \%)$ & $(100 \%)$ \\
\hline Stage 4 & Step 10; & 13 & 5 & 18 \\
\hline Supporting a Brand Asset & Measuring your return on brand investment & $(72 \%)$ & $(28 \%)$ & $(100 \%)$ \\
\hline \multirow[t]{2}{*}{ Management Culture } & Step 11; & 13 & 5 & 18 \\
\hline & Establishing a brand-based culture & $(72 \%)$ & $(28 \%)$ & $(100 \%)$ \\
\hline
\end{tabular}

Source: Author's research

The least registered activities are those related to measuring company's return on brand investment and establishing a brand-based culture (steps 10 and 11). These two groups of activities are present at only five banks surveyed (28\%). It is significant that the five banks where these two groups of activities were registered (steps 10 
and 11) belong to the group of top six banks on the market of $\mathrm{BiH}$ (measured by the amount of credit portfolio).

This can be one of the indicators of the importance of the full scale approach to brand management. These five banks are in the group of banks that implement nine to eleven steps in the tested Davis model in their brand management process. In order to assess the development of the brand management process for the banks surveyed, the model consisting of two criteria shall be adopted: a) presence of the systematic or the ad hoc approach to making brand management related decisions, and b) the number of steps as described in the Davis model that are present in the brand management process. The model is illustrated in Table 2.

Table 2. Applied model of assessment of the development of the brand management process for the banks in $\mathrm{BiH}$

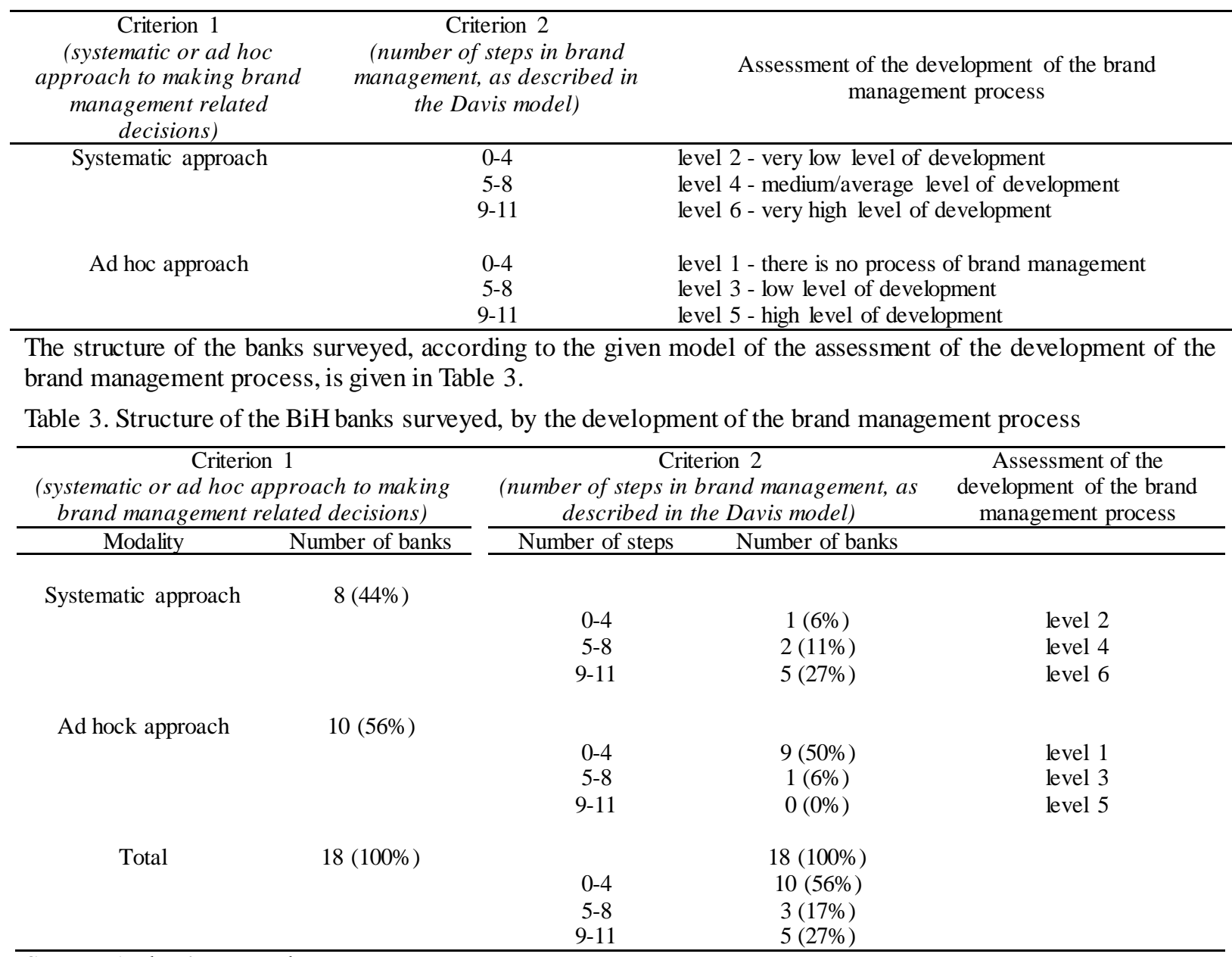

Source: Author's research

Out of the eight banks surveyed (44\%) with the systematic approach to brand management, five of them (63\%) create and develop their brand through the process consisting of nine to eleven steps (as described by the Davis model). These banks have a very highly developed process of brand management. Two banks (25\%) have a medium/average level of brand management development (level 4 on a development scale from 1 to 6). According to this criterion, $50 \%$ of the surveyed banks do not have the formal process of brand management (development level 1) but rather a unplanned activity realized through four or less steps (as observed by the Davis model). A more detailed structure of the banks in $\mathrm{BiH}$ by the level of development of the brand management process is given in Table 3.

\subsection{Sources of Input for Making Decisions Related to Brand Developmentfor the Banks in BiH}

The subjects confirming the implementation of the steps from the Davis model in creating and de veloping their brands, were asked to clarify the input based on which they make the decisions related to individual steps in the brand management process. The results are given in Figure 2. All the subjects in this segment stated that while planning and creating the decisions related to brand management they use information base on their personal experiences, which was rather expected as the brand management process is a constant activity and personal experiences are always welcomed. However, personal experience and assessment must not be the only input for 
making the decisions related to creating and de veloping brand. It is extremely important that such decisions, among other things, are based on the data collected through market research focusing on clients' perception, behavior, and satisfaction. Naturally, successful brand management requires the data gathered on the basis of monitoring the activities of the benchmark competitors.

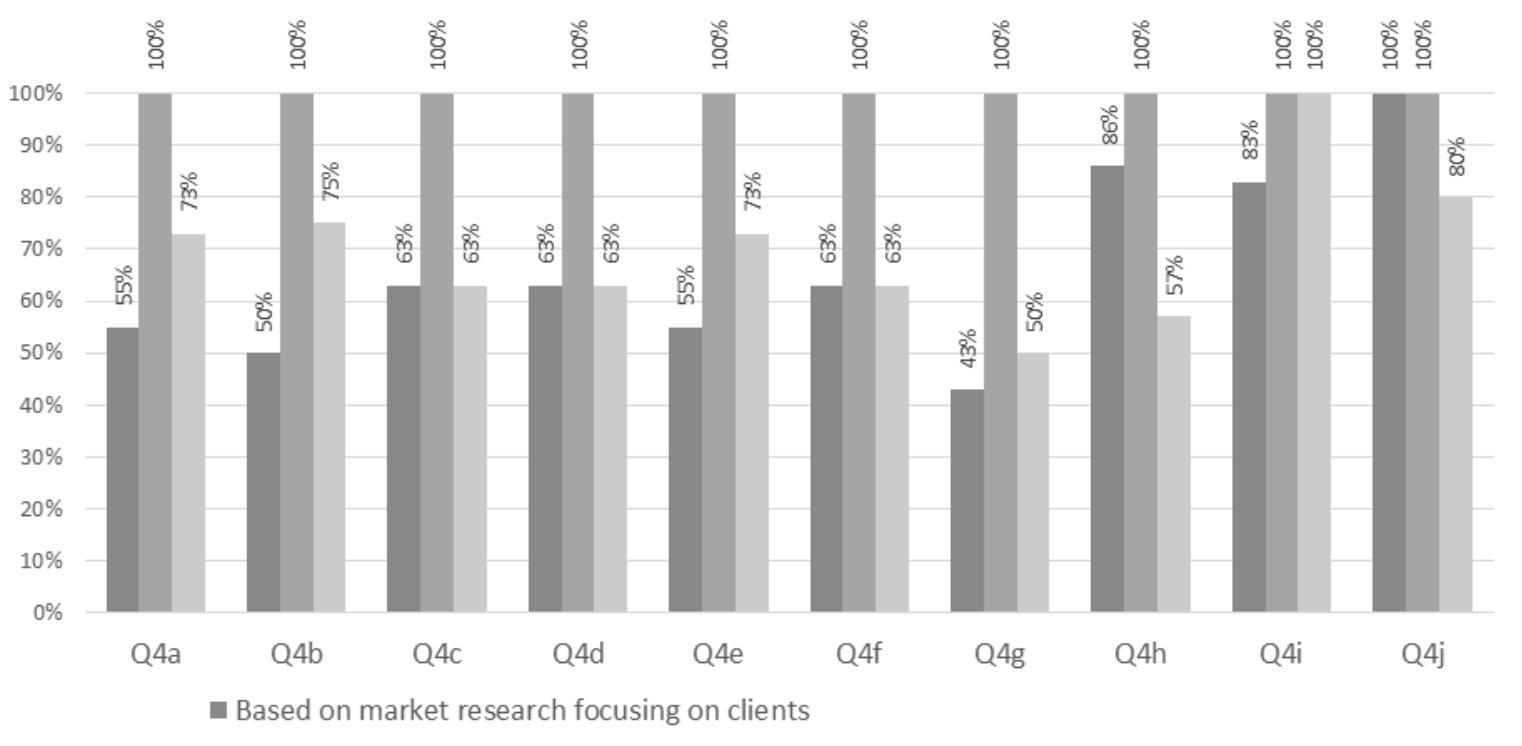

- Based on one's own experience and assessment

$\square$ Based on monitoring the activities of the benchmark competitors

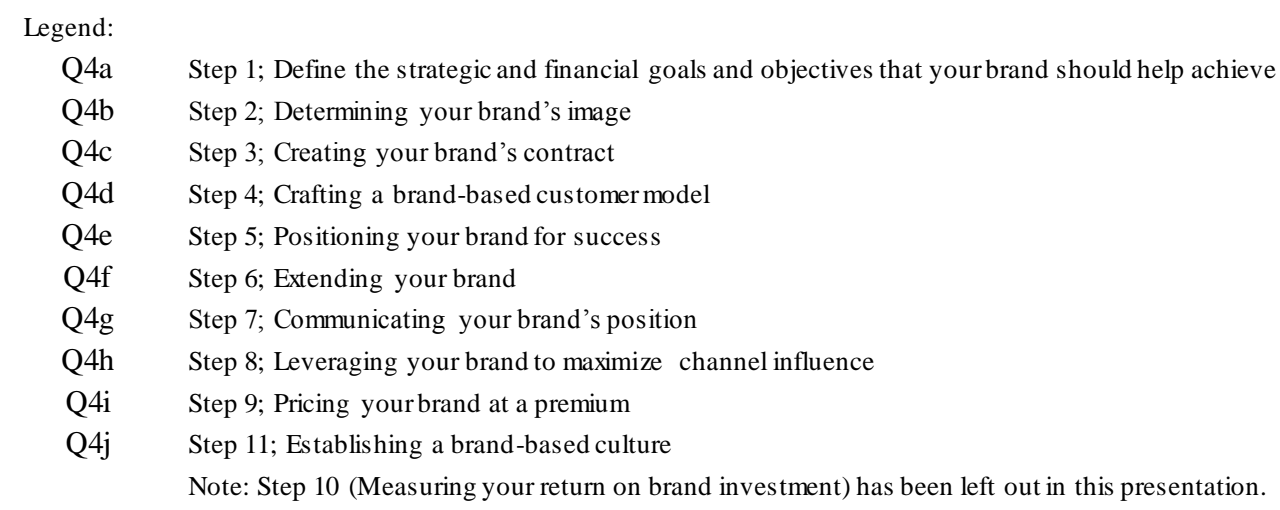

Figure 2. Input for making decisions in the brand management process for the banks in BiH (Author's research)

The information based on the research of clients' perception, behavior, and satisfaction is present in making decisions related to step 11 (establishing a brand-based culture) for all the banks that implement this step in their brand management process. Such information is also rather used while making decisions related to leveraging the brand to maximize channel influence (step 8) and while making decision on pricing the brand at a premium (step 9). This input was registered at $86 \%$ of the banks that implement step 8 in their brand management process and at $83 \%$ of the banks that implement step 9 in this process.

The input based on the research of clients' perception, behavior, and satisfaction is least registered while making decisions related to communicating the brand's position (step 7) and those related to determining the brand's image (step 2), which is rather surprising. Namely, this input is registered at $43 \%$ of the banks implementing step 7 and at $50 \%$ of the banks implementing step 2 in the brand management process. This is not a good indicator for marketing managers at the banks that do not use this input while deciding on brand management, as it is very important to create the solutions that would be accepted and properly perceived by the clients.

Using the input by means of monitoring the benchmark competitors is present for all the banks of the surveyed segment when they decide on pricing the brand at a premium (step 9), which is rather expected, taking into consideration the high level of competition on the banking market. It is interesting that while making decisions 
during the brand management process, the input from monitoring competitors is relatively more used than the input gained from client research.

\subsection{Approach to Brand Management for the Banks in BiH}

For the brand of a bank to have a successful market position, brand management needs to be connected to other aspects of market operations of the bank. Brand management is not an independent process and it is necessary for it to be integrated with other marketing processes at a bank. That is why it was considered important for this research to examine the attitudes of the banks surveyed towards certain statements that reflect the approaches to bank's brand management. The research results are given in Table 4 .

Table 4. Characteristics of approaches to brand management for the banks in $\mathrm{BiH}$

\begin{tabular}{|c|c|c|c|c|}
\hline \multirow{2}{*}{$\begin{array}{l}\text { Ordinal } \\
\text { number }\end{array}$} & \multirow{2}{*}{ Statements } & \multicolumn{3}{|c|}{ Refers to the surveyed banks } \\
\hline & & No & Yes & $\sum$ \\
\hline 1 & $\begin{array}{l}\text { We first design the desired perception of our brand from clients' } \\
\text { perspective and then constantly make promotional activities to inform the } \\
\text { clients. }\end{array}$ & $\begin{array}{c}11 \\
(61 \%)\end{array}$ & $\begin{array}{c}7 \\
(39 \%)\end{array}$ & $\begin{array}{c}18 \\
(100 \%)\end{array}$ \\
\hline 2 & $\begin{array}{l}\text { Through our business policy we constantly, over a longer period of time, } \\
\text { develop the characteristics of our brand. }\end{array}$ & $\begin{array}{c}12 \\
(67 \%)\end{array}$ & $\begin{array}{c}6 \\
(33 \%)\end{array}$ & $\begin{array}{c}18 \\
(100 \%)\end{array}$ \\
\hline 3 & $\begin{array}{l}\text { Our bank first designs the characteristics of the brand and creates the } \\
\text { activities needed for brand development that are then built into our } \\
\text { business plan. }\end{array}$ & $\begin{array}{c}11 \\
(61 \%)\end{array}$ & $\begin{array}{c}7 \\
(39 \%)\end{array}$ & $\begin{array}{c}18 \\
(100 \%)\end{array}$ \\
\hline 4 & $\begin{array}{l}\text { Brand related activities are the part of all our activities related to the } \\
\text { development of bank's business strategy. }\end{array}$ & $\begin{array}{c}11 \\
(61 \%)\end{array}$ & $\begin{array}{c}7 \\
(39 \%)\end{array}$ & $\begin{array}{c}18 \\
(100 \%)\end{array}$ \\
\hline
\end{tabular}

Source: Author's research

A small share of the banks (one third of the surveyed banks) has the approach by which they try to develop the characteristics of their corporate brand through their business policy over a longer period of time. The remaining two thirds of the surveyed banks do not have such an approach. For $61 \%$ of the banks surveyed, the activities related to brand development do not belong to bank's business strategy. The approach to brand management for the banks that denied the statements given in Table 4 (the banks that ans wered "no") is characterized by the lack of a long term and strategic orientation in this very important segment of market operations. Unfortunately, a small number of banks in $\mathrm{BiH}$ (39\% of them) have a strategic approach to brand creation and development. The approach to brand management for these banks is characterized by the long term planning of activities related to brand de velopment and integration of all these activities into the total business plans of a bank. This enables the bank to build successful market position in the long term, because seven banks that confirmed the statements given in Table 4 (the banks that answered "yes") are the top seven banks measured by the level of credit portfolio on the market of $\mathrm{BiH}$.

\section{Conclusion}

Summary of the findings: Brand management is strategically important for company's market success and the importance of brand is particularly evident in the banking sector. The relationship between a bank and a client requires a high level of trust and corporate brand in particular is the instrument of the market performance to which marketing managers connect the values they want to be the focal point of their relationship with the clients. It is very important for the communicated values to reflect the real relationship that would be developed with the clients. Communication with the clients serves as the channel for presenting the values under which a bank wants to be recognized on the market and that is when expectations are created for clients. The process of service delivery needs to fulfill (realize) the created expectations as otherwise it would cause disappointment for clients, which is something that should not happen by any chance. That is why the paper points to the importance of banks to connect their brand management to other segments of bank's business strategy, which would enable the integration of all the important elements determining the long term relations with clients.

The research results confirm Hypothesis 1 that there is no high level of development of brand management process for most banks in $\mathrm{BiH}$. The research included $90 \%$ of the banks operating on the market of $\mathrm{BiH}$. For $50 \%$ of the banks surveyed there is no formal process of brand management (development level 1). For $23 \%$ of the banks surveyed, the level of development of the brand management process is low and medium (development level 2, 3, and 4). Therefore, $73 \%$ of the banks surveyed do not have the formal or have low to medium developed process of brand management. Consequently, the research results indicate that $27 \%$ of the banks surveyed that operate on the market of $\mathrm{BiH}$ have a high level of development of the brand management process. All this confirms Hypothesis 1.

The research results indicate that $44 \%$ of the banks surveyed have a systematic approach to making decisions 
related to brand management while for $56 \%$ of them these decisions are made on the basis of an ad hoc approach. Besides, some $50 \%$ of the banks do not conduct market research on clients' perception, behavior, and satisfaction while making decisions related to steps 1,2,5, and 7 in the brand management process. In addition, $67 \%$ of the banks surveyed do not have an approach to brand management that they might use and de velop their corporate brand through their business policy in the long term. For $61 \%$ of the banks surveyed, the activities related to brand management are not the part of the development of their whole business strategy. Based on all this, Hypothesis 2 might be confirmed that for most banks in $\mathrm{BiH}$ the decisions related to brand management are made based on the ad hoc approach.

Managerial implications/management knowledge: The research results are significant for marketing managers at banks. The importance of brand management for banks' market success has been confirmed by the research results presented in this paper. Five banks assessed to have a high level of development of brand management belong to the group of top 6 banks on the banking market in $\mathrm{BiH}$ (measured by the amount of credit portfolio). Other banks have medium and low level of development of the brand management process. Also, it is extremely important for marketing managers to recognize the necessity for the systematic approach to brand management. In other words, brand management cannot be an isolated process, it needs to be connected and harmonized to other business segments and the part of the whole system of bank management. The research results show that seven banks with the long term approach to brand management integrated with the development of the whole business strategy of a bank belong to the group of top 7 banks on the banking market in $\mathrm{BiH}$. The third important issue is that making decisions related to brand management should not be based solely on personal experiences and assessments and monitoring competitors, but also requires the collection of data on clients' perception and their satisfaction. The data obtained in such way can significantly increase the success of the brand management process.

Research limitations: The research results provided significant scientific evidence. However, the research also has certain limitations. They are primarily related to the fact that the research did not include the content of the decisions made within individual steps in the brand management process. In addition, the research did not measure the influence of the brand on certain aspects of market success of banks, which would indicate a more clear influence of the brand on banks' market performances.

Recommendation for further research: The further research should primarily focus on two topics. First, the research into the content of individual steps in the brand management process would identify the factors determining the success of the brand management process, which would be a significant know-how in the segment of marketing management in banking. Second, the research into clients' perceptions on certain brands on the banking market and the factors used by clients when making decisions on which banks to choose, would generate extremely important scientific evidence on the specific features of creating and developing brand for the banks on the market of $\mathrm{BiH}$.

\section{References}

Centralna banka Bosne i Hercegovine/ The Central Bank of Bosnia and Herzegovina. (accessed February 2017). http://cbbh.ba/Content/Read/7

Davis, S. (2002). Brand Asset Management: Driving Profitable Growth Through Your Brands. New York: John Wiley \& Sons Inc.

De Chernatony, L. (2006). From Brand Vision to Brand Evaluation: The strategic process of growing and strengthening brands (2nd ed.). Oxford: Elsevier and Butterworth-Heinemann.

Keller, K. L. (2003). Strategic Brand Management. New York: Prentice Hall.

Kotler, F., \& Ferč, V. (2007). B2B brend menadžment. Novi Sad: Adižes.

Šapić, D. (2007). Volim brend, živim za brend. Belgrade: Dejan Šapić.

Veljković, S. (2010). Brend menadžment u savremenim tržišnim uslovima. Belgrade: CID of the Faculty of Economics in Belgrade.

Vranešević, T. (2007). Upravljanje markama. Zagreb: Accent.

\section{Copyrights}

Copyright for this article is retained by the author(s), with first publication rights granted to the journal.

This is an open-access article distributed under the terms and conditions of the Creative Commons Attribution license (http://creativecommons.org/licenses/by/4.0/). 